\title{
PREDICTION POWER PROPULSION OF THE SHIP \\ AT THE STAGE OF PRELIMINARY DESIGN \\ Part II: MATHEMATICAL MODEL SHIP POWER PROPULSION FOR SERVICE SPEED USEFUL IN THE PRELIMINARY DESIGN
}

\author{
Tadeusz SZELANGIEWICZ, Katarzyna ŻELAZNY \\ Maritime University of Szczecin
}

\begin{abstract}
:
During the design of the ship the most important decisions are made at the stage of preliminary design. One of the most important design parameters assumed by the shipowner is its service speed in real weather conditions occurring in the shipping line. For this speed, at the stage of preliminary design, when are known only to the basic geometric parameters of the ship should be determined motor power. In practice design, power propulsion is determined with a very approximate formulas but for the speed in calm water. Only after the project contract and the signing of the contract are carried out by means of resistance and self-propulsion of model test. The paper presents a mathematical model for determining the power propulsion for the assumed operating speed. This model is dependent only on the basic geometric parameters of the hull of the ship and the weather parameters occurring in liner shipping. Also shows the results of calculations according to this model, the power propulsion for one of vessels built.
\end{abstract}

Key words: power propulsion, service speed, preliminary design

\section{MATHEMATICAL MODEL OF TOTAL RESISTANCE TRANSPORT VESSEL IN REAL WEATHER CONDITIONS}

To calculate the power propulsion needed to achieve service speed in real weather conditions must know the total resistance which occurs in these conditions and thrust propeller.

The total resistance of the vessel in real weather conditions on a given shipping route:

$$
R_{C}=R+\Delta R
$$

where:

$\mathrm{R}$ - ship resistance in calm water,

$$
\Delta R=R_{x A}+R_{x W}+R_{x R}
$$

$R_{x A}$ - additional resistance from the wind, (Fig. 1),

$\mathrm{R}_{\mathrm{xW}}$ - additional resistance from the waves, (Fig. 1),

$\mathrm{R}_{\mathrm{XR}}$ - additional resistance of e.g. steering devices (e.g. rudder fin), that keep vessel on a given course (disturbance of the course are also caused by the impact of wind and wave).

During the cruise on the set of the shipping line to the ship may be affected by surface sea current, wind and wave from any direction, in addition to resistance lengthwise, will be created lateral forces that cause drift of the ship (angle $\beta)$ and the moment around the vertical axis causing the change rate (angle $\psi$ ) - Fig. 1 . To keep the ship on course to be given to swing the rudder blade (angle $\delta$ ), which will generate an additional resistance to longitudinal and lateral forces - Fig. 1.

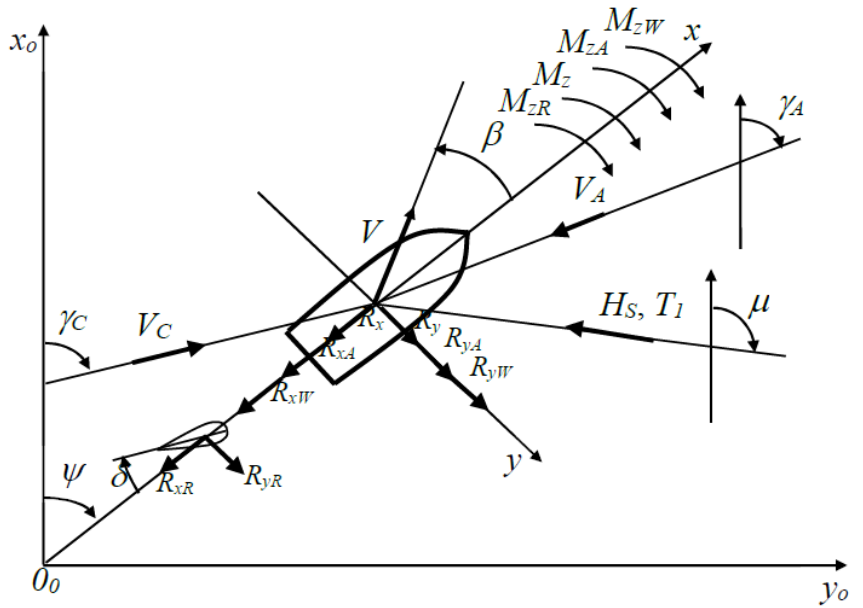

Fig. 1 The components of the total resistance of the ship (sea water flow: $R_{x}, R_{y}, M_{z} ;$ wind: $R_{x A}, R_{y A}, M_{z A}$; wave: $R_{x W}, R_{y w}, M_{z w}$ rudder fin: $\left.R_{x R}, R_{y R}, M_{z R}\right)$; speed $V$, the angle of the exchange rate $\psi$ and drift angle $B$ ship; current parameters $V_{C} \gamma_{c}$; wind: $V_{A}, \gamma_{A} ;$ wave: $H_{S}, T_{1}, \mu$; the angle of the rudder $\delta$

From Figure 1 shows that the ship floating on the set of the shipping line in the actual weather conditions, to determine the total resistance must be known to all the components of the individual components, equations (1) and (2), the character of these components for cargo ships is presented in $[4,5]$ - to calculate these components is necessary to know the value of a large number of parameters, as well as the results of model tests and the delivery- 
acceptance after the construction of the ship. So in order to develop a model of service speed, which is useful in the preliminary design, specify patterns approximation, dependent only on the basic dimensions of vessels for all components of total resistance. A method for approximation of the models presented in [5].

Final figures function approximation component of total resistance for ships bulk carriers are:

- resistance to water and sea current:

$R_{x}=\left(3.7509-1.5 \cdot 10^{-7} L_{W L}^{3}+2.4 \cdot 10^{-4} B^{2} \ln (B)-6.39 \cdot 10^{-4} T^{3}-\right.$

$$
-13.6864\left(\ln \left(C_{B}\right)\right)^{2}+
$$

$\left.+1.73 \cdot 10^{-5} \nabla \ln (\nabla)\right) V^{2} \cdot\left(-0.00085 \beta^{2}+0.07715 \beta+1\right)$

$R_{y}=\rho_{w} L T V^{2}\left(8.09 \cdot 10^{-5} \beta^{2}+1.3 \cdot 10^{-3} \beta\right)$

$M_{z}=8.55 \cdot 10^{-4} \rho_{w} T L^{2} V^{2} \beta$

- the effect of wind:

$$
R_{x A}=-\frac{1}{2} \rho_{A} \cdot(233.71 \cdot \ln (\nabla)-1879.3) \cdot V_{R A}^{2} .
$$

$\left(0.4770+0.01528 \cdot \beta_{R A}-3.202 \cdot 10^{-4} \cdot \beta_{R A}^{2}+1.060 \cdot 10^{-6} \cdot \beta_{R A}^{3}\right)$,

$R_{y A}=\frac{1}{2} \rho_{A} \cdot(895.4 \cdot \ln (\nabla)-7472.4) \cdot V_{R A}^{2}$.

$\cdot\left(-0.01529+0.01529 \cdot \beta_{R A}-8.710 \cdot 10^{-5} \cdot \beta_{R A}^{2}\right)$,

$$
M_{z A}=\frac{1}{2} \rho_{A} \cdot(895.4 \cdot \ln (\nabla)-7472.4) \cdot L \cdot V_{R A}^{2} .
$$

$\cdot\left(-0.0071 \cdot \beta_{R A}+0.0001 \cdot \beta_{R A}^{2}-7 \cdot 10^{-7} \cdot \beta_{R A}^{3}+1 \cdot 10^{-9} \cdot \beta_{R A}^{4}\right)$.

- the effect of wave:

$$
\begin{gathered}
R_{x W}, R_{y W}, M_{z W}=f\left(x_{1} \cdots x_{k}\right)= \\
=\sum_{i=1}^{11}\left(c_{i} \cdot\left(\frac{2}{1+e^{-2 \cdot\left(\sum_{k=1}^{9} a_{i, k} x_{k}+b_{i}\right)}}-1\right)\right)+D
\end{gathered}
$$

where:

$x_{k}=\left[L, B, T, C_{B}, C_{W P}, F_{w}, V, \beta_{W}, H_{s}\right]$, whereas $a, b, c, D$ are parameters of artificial neural networks developed [5],

- the resistance of the rudder fin:

$$
\begin{gathered}
R_{x R}=\left|(0.0194 \cdot L \cdot T+2.1874) \cdot c \cdot(a+b \cdot V)^{2}\left(\sin \delta_{R}\right)^{2}\right|, \\
R_{y R}=\frac{1}{2}\left(1.14-0,6 \cdot C_{B}\right) \cdot(0.0194 \cdot L \cdot T+2.1874) . \\
\cdot c \cdot(a+b \cdot V)^{2} \sin 2 \delta_{R}, \\
M_{z R}=-\frac{1}{4} L\left(1.14-0.6 \cdot C_{B}\right) \cdot(0.0194 \cdot L \cdot T+2.1874) . \\
\cdot c \cdot(a+b \cdot V)^{2} \sin 2 \delta_{R},
\end{gathered}
$$

where:

$$
c=\left(\frac{1}{2} \rho_{w} \frac{6,13 \lambda}{\lambda+2,25}\right) ; a=4.252 ; b=0.262 ; \lambda=1695
$$

The approximation formulas have been developed on the basis of technical-operational parameters built ships (base A). For those ships were carried out statistical tests developed function approximation, while the substantive tests were carried out for the second group of vessels (base B) built in the Szczecin Shipyard. In Fig. 2-3 shows a few examples of substantive tests designed function approximation.

Designs approximation components of total resistance to other types of ships and substantive testing are presented in [5].

\section{MATHEMATICAL MODEL OF THRUST OF THE PROPELLER AND EFFICIENCY COEFFICIENTS}

In addition to the total resistance, to determine the power propulsion in the actual weather conditions at the stage of preliminary design is necessary mathematical model propeller and efficiencies coefficient. As in the case of the components of total resistance, also for these values must be developed approximation functions depend only on the main dimensions of the ship - great way to find these functions approximation presented in [5]. Final figures approximating the function parameters of the screws and the coefficients to calculate the propulsive efficiency for ships bulk carriers are the following:

1. Propeller:

- pressure T and torque Q:

$T, Q=f\left(x_{1} \cdots x_{k}\right)=\sum_{i=1}^{11}\left(c_{i} \cdot\left(\frac{2}{1+e^{-2 \cdot\left(\sum_{k=1}^{7} a_{i, k} x_{k}+b_{i}\right)}}-1\right)\right)+D$

where:

$x_{k}=\left[L, B, T, C B, \nabla, V, n_{p}\right]$, whereas $a, b, c, D$ are parameters of artificial neural networks developed [5],

- diameter of the propeller:

$$
D_{P}=-0.4774 \cdot T^{2}+401.18 \cdot T+1517.5
$$

where:

$\mathrm{T}$ - draft of the ship,

- propeller advance coefficient:

$$
J=\frac{V_{E}\left(1-w_{T}\right)}{n \cdot D_{P}}
$$

2. Factors to the efficiency drive:

- thrust deduction fraction:

$$
t=0.067036+0.059741 \cdot C_{P}+0.585806 \cdot \frac{B}{L}
$$

- wake coefficient:

$$
\begin{gathered}
w_{T}=-1.11851+0.00369 \cdot B+2.0656 \cdot C_{P}- \\
-0.364233 \cdot \frac{T}{B}-7.6 \cdot 10^{-7} \cdot \nabla
\end{gathered}
$$

- rotative efficiency:

$$
\begin{aligned}
& \eta_{R T}=0.99660+0.094350 \cdot C_{P}- \\
& -0.000012 \cdot T \cdot B+0.021510 \cdot \frac{B}{L}
\end{aligned}
$$



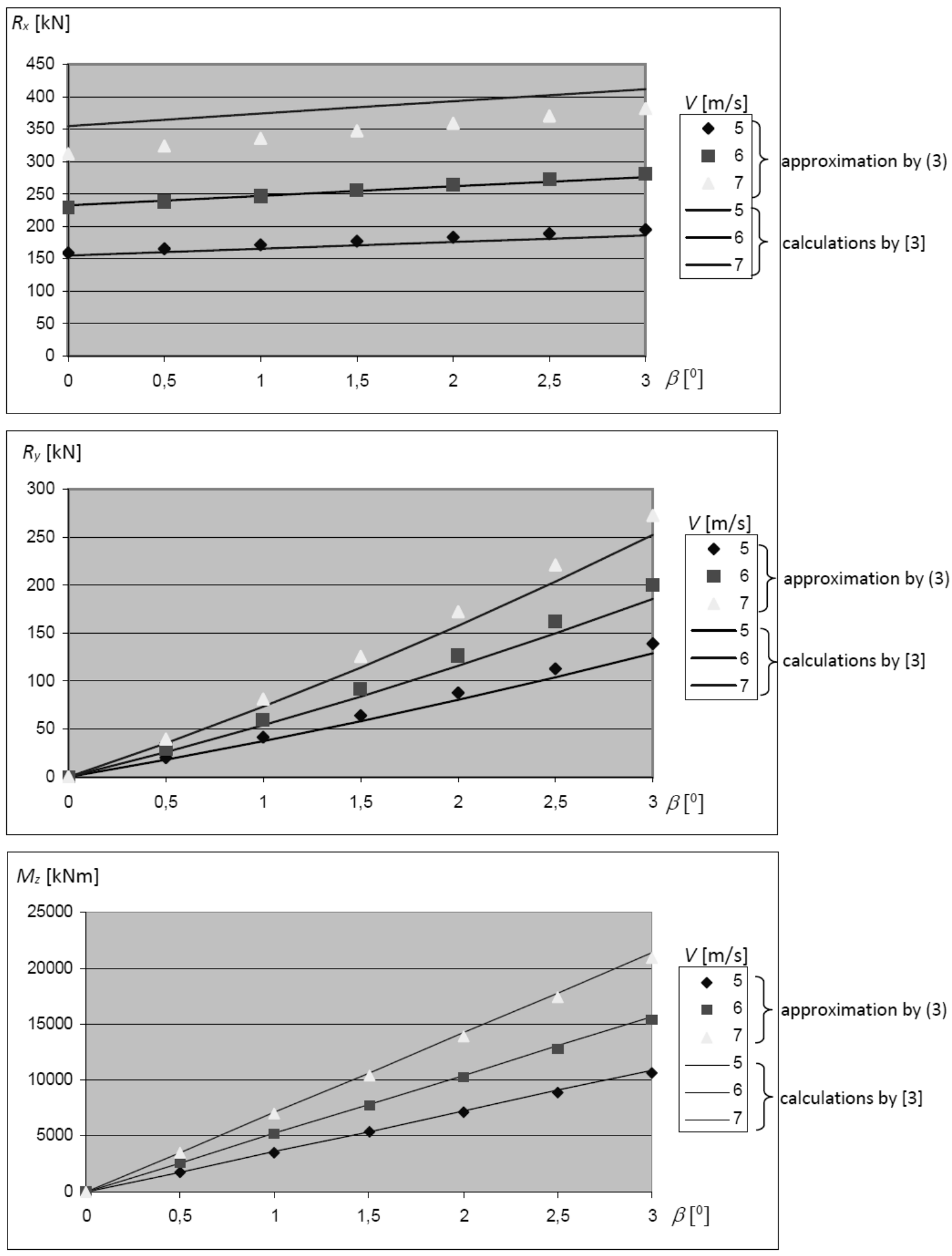

Fig. 2 The forces and moment of resistance of the ship in calm water, taking into account the angle of drift for various vessel speed $V$ - bulk carrier $M 1$ 

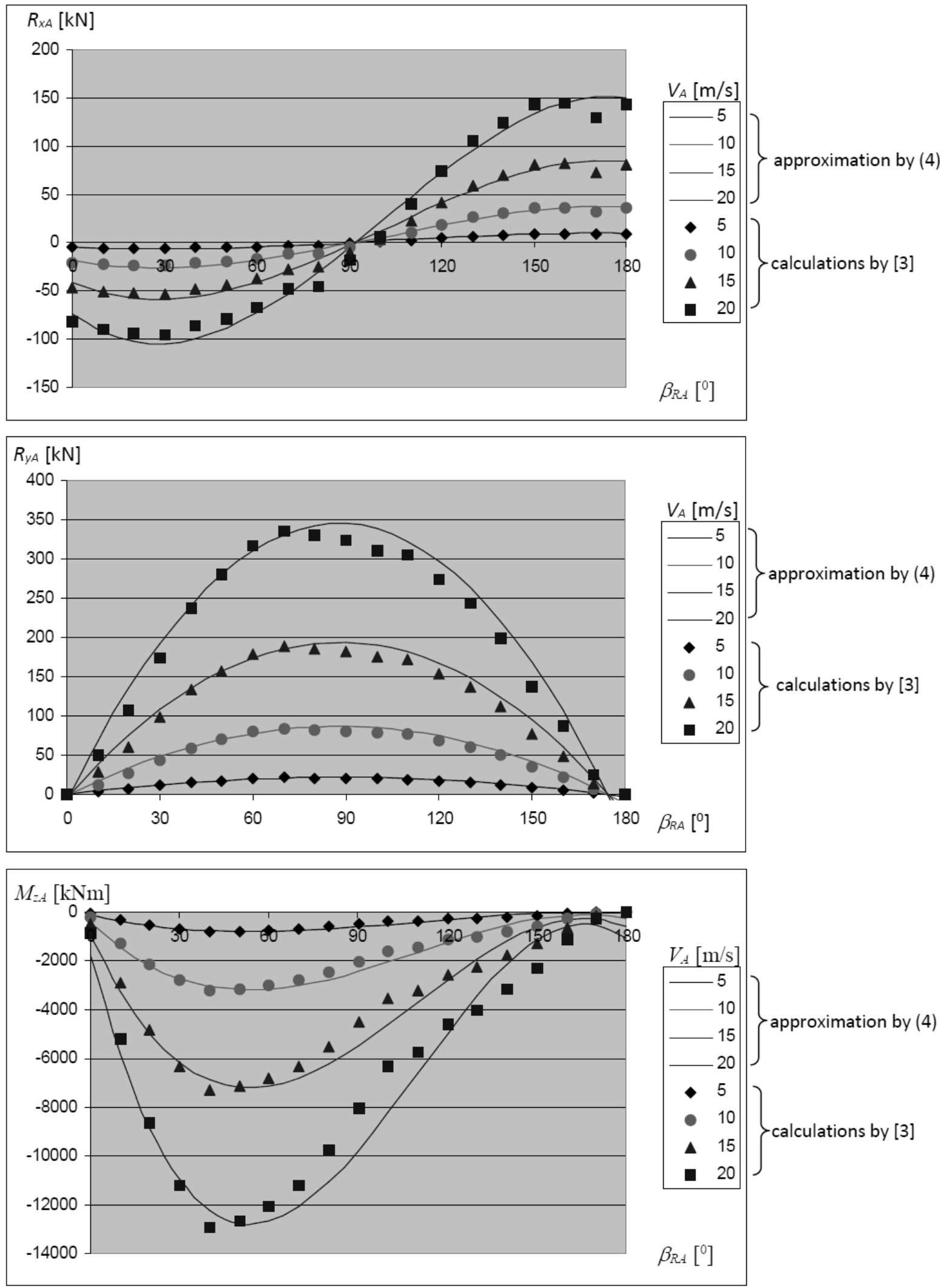

Fig. 3 The forces and moment from the wind for different wind speeds $V_{A}$ - bulk carrier M1 
As in the case of total resistance, the function approximation for the parameters of the propeller and efficiencies statistical tests were performed for ships with a base $A$, a substantive test vessels from the base $B$.

\section{MATHEMATICAL MODEL OF THE POWER PROPULSION TO THE SERVICE SPEED, WHICH IS USEFUL AT THE STAGE OF PRELIMINARY DESIGN}

Power to the motor coupling $P_{B}$ is equal to the main drive [1]:

$$
P_{B}=\frac{P_{E}}{\eta}
$$

where:

$\mathrm{P}_{\mathrm{E}}$ - towing power,

$\eta$-overall efficiency propulsion.

Since the power $\mathrm{P}_{\mathrm{B}}$ is to be determined for a service speed which the ship is achieved at a given shipping line to:

$$
P_{E}=V_{E} \cdot R_{C}
$$

where:

$V_{E}$ - reference, statistical average service speed of the ship on a shipping line in the actual weather conditions,

$\mathrm{R}_{\mathrm{C}}$ - the total resistance (statistical average) in the actual (average statistics) weather conditions for shipping.

The overall efficiency of the propulsion of the vessel is equal to:

$$
\eta=\eta_{G} \cdot \eta_{S} \cdot \eta_{H T} \cdot \eta_{0} \cdot \eta_{R T}
$$

where:

$\eta_{G}$ - efficiency of the assembly, if used,

$\eta_{\mathrm{s}}$ - efficiency shafting,

$\eta_{\mathrm{HT}}-$ impact factor of the hull:

$$
\eta_{H T}=\frac{1-t}{1-w_{T}}
$$

$\mathrm{t}$ - thrust deduction coefficient,

$\mathrm{w}_{\mathrm{T}}$ - wake coefficient,

$\eta_{R T}-$ rotative efficiency,

$\eta_{0}$ - propeller efficiency (without the hull of the vessel):

$$
\eta_{0}=\frac{J}{2 \pi} \cdot \frac{T \cdot D_{P}}{Q}
$$

$T$ - the thrust of the propeller,

$\mathrm{Q}$ - the torque of the propeller,

$D_{P}$ - diameter of the propeller,

$\mathrm{J}$ - propeller advance coefficient.
To the formula (13) can be calculated power propulsion $P_{B}$, for a given service speed $V_{Z E}$ at the stage of preliminary design, all sizes must be dependent only on the basic geometric parameters of the designed ship and the weather parameters occurring in the shipping line.

Nominal power of the motor is thus equal to:

$$
N_{n}=\frac{P_{B}}{0.9}=\frac{V_{Z E} \cdot\left(R_{x}+R_{x A}+R_{x W}+R_{x R}\right)}{\eta_{G} \cdot \eta_{S} \cdot \frac{1-t}{1-w_{T}} \cdot \frac{J}{2 \pi} \cdot \frac{T \cdot D_{P}}{Q} \cdot \eta_{R T}}
$$

Substituting equation (18) by:

- $R_{C}$ - the expression (1)-(6),

- $\eta_{H T}-$ the expression (10), (11),

- $\eta_{0}$ - the expression (7)-(9),

- $\eta_{R T}$ - the expression (12), obtained equation for $\mathrm{N}_{\mathrm{n}}$ or $\mathrm{P}_{\mathrm{B}}$ depend on the weather conditions (parameters of wind, sea current and waves) and the basic geometrical parameters of the designed ship: length $L$, breadth $B$, draught $T$, side height $H$, displacement $\nabla$, bulk coefficient $C_{B}$, waterplane coefficient $C_{W P}$, longitudinal prismatic coefficient $C_{P}$.

\section{THE RESULTS OF CALCULATIONS OF POWER PROPULSION}

For the ship M1 (bulk carrier) with dimensions:

$\mathrm{L}=138.0 \mathrm{~m}$

$\mathrm{B}=23.0 \mathrm{~m}$

$\mathrm{T}=8.5 \mathrm{~m}$

$\mathrm{C}_{\mathrm{B}}=0.804$

$\mathrm{C}_{\mathrm{WP}}=0.892$

$C_{P}=0.809$

It has been designed for the speed of contract $V_{K}=7.33$ $\mathrm{m} / \mathrm{s}$. On the basis of model tests specified nominal power of the drive motor $\mathrm{N}_{\mathrm{n}}=5720 \mathrm{~kW}$, and assuming the sea margin $\mathrm{SM}=15 \%$ of the estimated service speed $\mathrm{V}_{\mathrm{E}}=7.07 \mathrm{~m} / \mathrm{s}$.

What is the actual service speed of the vessel, calculated by the algorithm [4], the actual weather conditions on various shipping lines shown in Fig. 4.

Assuming that the ship is expected to reach a predetermined service speed $V_{Z E}=7.07 \mathrm{~m} / \mathrm{s}$ with the probability of its maintenance level $P_{V Z E}=95 \%$, nominal power of the engine, calculated from the formula (18) for various shipping lines is shown in Fig. 5.

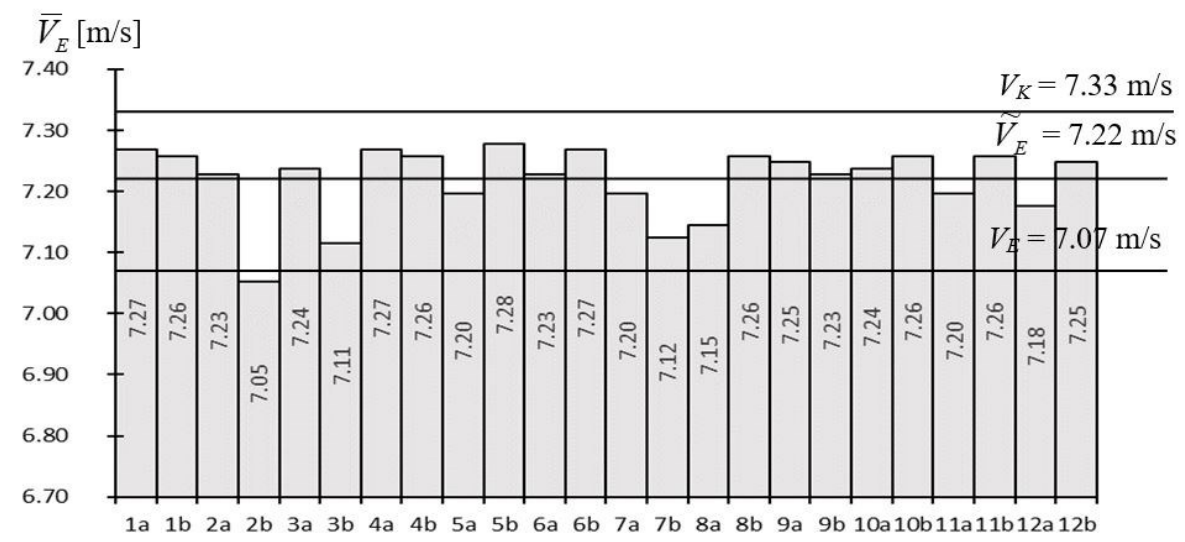

shipping line 


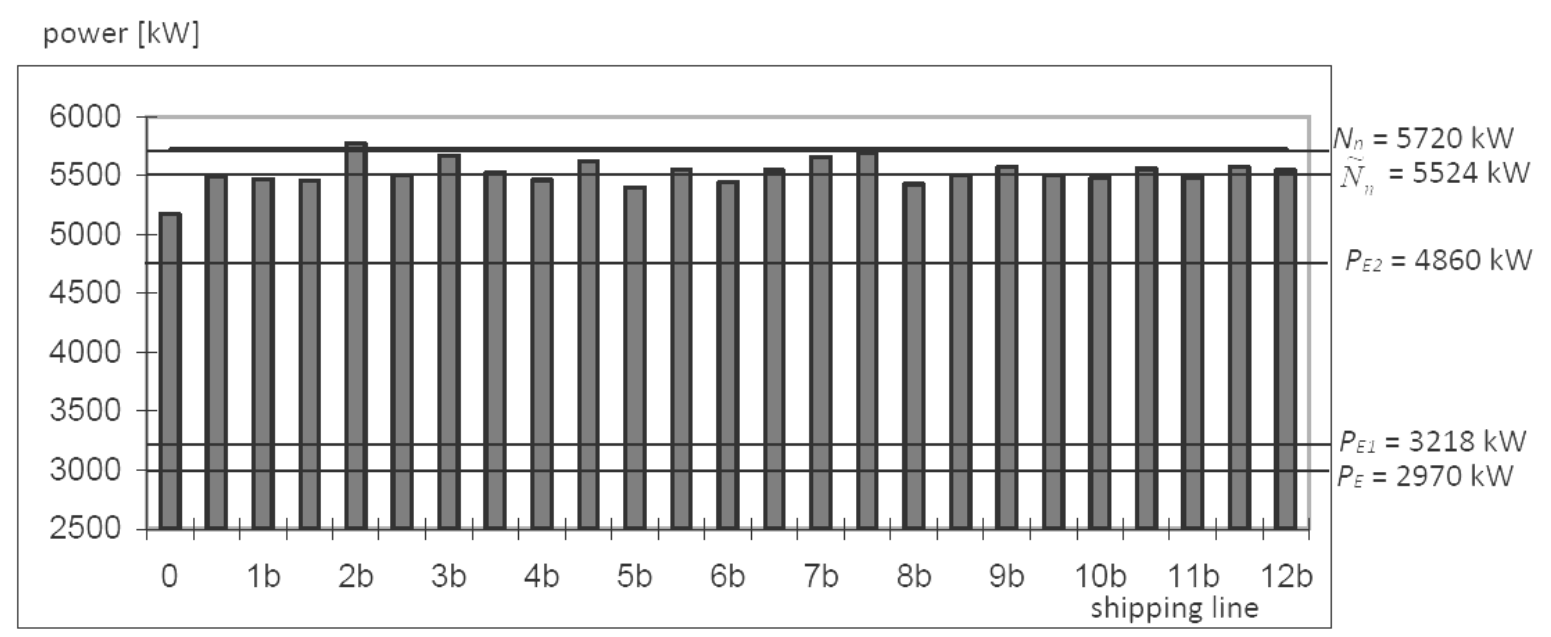

Fig. 5 Nominal power $N_{n}$ for the ship $M 1$

Explanations: $\tilde{N}_{n}$ - the average nominal power for all routes, $P_{E}$ - towing power (14), $P_{E 1}$ - power towing method of Silverleaf-Dawson [2], $P_{E 2}$ - power towing method of Watson [2]

\section{FINAL CONCLUSIONS}

1. Fig. 5 shows the results of calculations of the nominal power of the drive motor M1 ship for individual shipping lines and the average value for all analyzed shipping lines. The average value calculated from approximation formulas contain only the basic dimensions of the main ship, it is $3.5 \%$ lower than the nominal power $\mathrm{Nn}$ determined on the basis of model tests made after signing the contract.

2. Fig. 5 also shows the power of towing $P E$ and power towing calculated from two very approximate formulas [2] used at the stage of preliminary design. These formulas for the ship give a very inflated results.

3. The developed method of calculating power propulsion for the established service speed at the stage of preliminary design requires further research and testing, as presented in the article the results of calculations apply only to one vessel.

\section{REFERENCES}

[1] K. Chachulski, Podstawy napędu okrętowego, Gdańsk: Wydawnictwo Morskie, 1988.

[2] J.P. Michalski, Podstawy teorii projektowania okrętów, Gdańsk: Wydawnictwo Politechniki Gdańskiej, 2013.

[3] T. Szelangiewicz, „Wpływ kotwicznego systemu utrzymania pozycji na kołysania statku w obecności wiatru, prądu i falowania", Prace Naukowe Politechniki Szczecińskiej, no. 523, Szczecin: Wydawnictwo Uczelniane Politechniki Szczecińskiej, 1995.

[4] K. Żelazny, „Numeryczne prognozowanie średniej długoterminowej prędkości eksploatacyjnej statku transportowego", Ph.D. dissertation, Faculty of Maritime Technology and Transport, West Pomeranian of Technology in Szczecin, Szczecin, 2005.

[5] K. Żelazny, Metoda wyznaczania prędkości eksploatacyjnej przydatna w projektowaniu wstępnym statków transportowych w statystycznych warunkach pogodowych występujqcych na liniach żeglugowych, Szczecin: Wydawnictwo Uczelniane Zachodniopomorskiego Uniwersytetu Technologicznego w Szczecinie, 2015.

\section{prof. dr hab. inż. Tadeusz Szelangiewicz,} dr hab. inż. Katarzyna Żelazny, prof. AM Maritime University of Szczecin, Faculty of Navigation, Wały Chrobrego 1-2, 70-500 Szczecin, POLAND e-mail: t.szelangiewicz@am.szczecin.pl k.zelazny@am.szczecin.pl 